\title{
COBBETT LETTERS IN THE LIBRARY
}

\section{BY C. REXFORD DAVIS}

PRofEssor Davis, who has already written two articles for the Journal on Cobbett, here describes the whole collection of Cobbett autograph letters in the Library.

THE LIBRARY possesses some ten Cobbett letters, which may be listed as follows:

I. Autograph letter signed, from New York to Robert Goodloe Harper, at Philadelphia, 20 January, I 800.

2. Autograph letter signed, from Hyde Park, Long Island, to William Jackson, at London, 7 June, I 8 I 7.

3. Autograph letter signed, from Chilworth, near Guildford, to William Palmer, at Bollitree Castle, Herefordshire, 5 January, I 829.

4. Copy of letter, from Bolt-Court to John Dean, at Normandy Farm, 6 September, I 833 .

5. Autograph letter signed, from Bolt-Court to John Dean, at Normandy Farm, Io September, I 833 .

6. Autograph letter signed, from Dublin, Ireland, to John Dean, at Normandy Farm, 26 September, I 834 .

7. Autograph letter signed, from Cork, Ireland, to John Dean, at Normandy Farm, 16 October, I 834 .

8. Autograph letter signed, from Normandy Farm to Jesse Oldfield, at Bolt-Court, I May, I 835 .

9. Autograph letter signed, from Godalming to Jesse Oldfield, at Bolt-Court, 8 May, I 835 .

Io. Autograph letter signed to Mr. Gutsell, at Normandy Farm, 2 I May, I 835 .

The first two of these letters were discussed in detail, and transcribed, in articles appearing in the December, I95 I, and the December, 1952, numbers of the Journal of the Rutgers University Library. The others deserve discussion also, although space in the Journal will not permit that they all be transcribed.

Letter 3, to William Palmer, a close friend whom Cobbett visited often in his rides up and down the southern counties of England, shows Cobbett's concern with two of his principal interests: the im- 
provement of English agriculture and his antagonism to the Bank of England and to its fiscal and financial policies. He begins by thanking Palmer for a plough especially designed for use in a nursery. (At Kensington Farm, which Cobbett operated at this date, one of his principal interests was growing trees for reforestation work.) $\mathrm{He}$ goes on to offer to give Palmer and his brothers each enough Indian corn seed to plant five acres. (The domestication of Indian corn in England was always a favorite object with Cobbett-he called it Cobbett's corn-but he never succeeded in this project, chiefly because most English summers are not hot enough to grow this grain with real success.) Finally he discusses the prospect of early bank failures; he really expects that the Bank of England will be shaken. He ends by saying of the banks:

They will, with all their votaries, go to the Devil at last: that's one thing: but, they will not pack up for hell without making horrible confusion in this world. I do really believe, that the whole thing will go to pieces this year.

Letters 4-IO the Library purchased in a group at auction in the late fall of 1952 . The seven as a group were preserved by Benjamin Tilly, one of Cobbett's several secretaries in the latter years of his life. Letter 4, indeed, is in Tilly's handwriting, for it is Tilly's copy of the letter actually sent, and it contains, besides, annotations by Tilly. The letter directs John Dean to give to Mr. Smith (presumably the bearer of the letter) certain books. Tilly in his annotations indicates that the several books listed belong to Mrs. Cobbett and Cobbett's several children, listing Nancy (Anne), Ellen (Eleanor), Susan, John, Richard, Mrs. C., and James. William Junior seems not to be involved. The letter does not tell us much, but its contents suggest that it may one day help to fill in the gaps in our uncertain knowledge about a severe but obscure family quarrel in Cobbett's last years. ${ }^{1}$

Letter 5 compliments Dean on his success in managing affairscertainly not farm operations - at Normandy Farm in a crisis of uncertain nature. Most of the information lies between the lines where it cannot at present be read. Perhaps the last paragraph may serve to demonstrate the difficulty:

Read this to Mr Swain and Mr Tilly. Tomorrow I shall get my statement ready, and send it back by $\mathrm{Mr}$ Gutsell on Thursday, or on Friday morning.

${ }^{1}$ See W. D. H. Cole, The Life of William Cobbett, Third Edition (London, 1947), p. $\mathbf{x}$. 
Be you well assured that nothing shall make me give way upon any one of the points that we spoke of.

John Dean had served Cobbett well upon many other occasions. When Cobbett died on June 17, 1835, Dean had served him in an executive capacity for over twenty-five years. In 18 io he had been foreman labourer on Cobbett's great farm at Botley, for we have his signature in that capacity as witness to an agreement dated April 8, I 8 Io. $^{2}$ When through bankruptcy Cobbett lost Botley, and then moved to Brompton and soon afterwards to Kensington, Dean was still his man. And when, in I 83 I, Kensington Farm and its satellite, Barn-Elm Farm, were both given up, and Normandy Farm leased, John Dean as a matter of course went along. Letters numbered 4 to 7 inclusive show how highly Cobbett regarded him.

Benjamin Tilly, as already stated, was one of Cobbett's secretaries. In this capacity he naturally had opportunity to preserve both manuscript material and other Cobbettiana. He had other opportunities after his employer's death, for he was Honorary Secretary of the Cobbett Club, "formed in London in 1838 , five [sic] years after Cobbett's death, by a group of his friends and admirers." "3 Of the letters in the Library the latter seven can be traced to Tilly. Letters 7 and 9 have explanatory notes in Tilly's hand with the initials "B.T." Letter 8 has at the end an explanatory note signed "B. Tilly." Other manuscripts preserved by Tilly are to be found in the British Museum and in the collection of Arnold Muirhead. Tilly also assembled a not inconsiderable group of Cobbett relics, now to be found in the Goldsmiths' Library at London University. ${ }^{4}$ It seems likely, then, that Tilly was important as an aide to Cobbett.

Gutsell and Swain must also have been essential to the operation of Cobbett's many enterprises. Gutsell, about whom I have as yet been unable to discover corroborative evidence, seems to have been a close friend and Man Friday rather than an employee in the ordinary sense. Letter Io, addressed to Gutsell, reads in part: "We must so settle things, that you may come along with me on Monday. ... It is not right, even if it were only your company, that I should not have the pleasure of that." Perhaps Gutsell served Cobbett as legal adviser, perhaps as some sort of political secretary, for at this time Cobbett was Member of Parliament for Oldham. Swain seems

\footnotetext{
2 M. L. Pearl, William Cobbett (London, r 953), p. 244.

3 Pearl, p. 205.

${ }^{4}$ Pearl, p. 205 n.
} 
to have had a position of some responsibility at Kensington Farm, but information is lacking. Since Dean managed the farm, Swain may have had responsibility for sales of books, seeds, trees, products of the farm, etc. In any event it is noteworthy that in this letter Cobbett gives each of the four his "Mr."

Jesse Oldfield, to whom Letters 8 and 9 are addressed at BoltCourt, Cobbett's publishing address in London, was in charge of Cobbett's shop there. These letters concern affairs of the shop, personal favors from Oldfield acknowledged and requested, the discharge of Cobbett's "Major-Domo" at Normandy Farm, one William Caeser, and financial difficulties of William Cobbett, Jr. Both letters will be of value to the future biographer when studied in conjunction with manuscript material available elsewhere.

There remain for discussion letters 6 and 7, addressed to John Dean from Ireland. Cobbett had often desired to see Ireland for himself. He had for years worked with Daniel O'Connell, the Irish patriot and orator, surnamed by the Irish "The Liberator." Constantly he sought to alleviate the conditions of the starving people, and he strove also for repeal of the Act of Union. Many times had O'Connell invited Cobbett to Ireland; as often he had desired to go but had felt unable to leave his many interests. However, in the summer of 1834 he at length made his plans, and he set off early in September. From Ireland he wrote ten letters to Charles Marshall, a laborer at Normandy Farm, letters which were duly printed in his Political Register weekly from September 27 to November 29. Everywhere in Ireland Cobbett was greeted by huge crowds and cheered most heartily; to the Irish he was scarcely less of a hero than O'Connell himself.

Letter 6, from Dublin, is headed "DIRECTIONS." It has eighteen numbered items and a postscript. The first item reads: "I. Keep all my letters; number them, read them over carefully, and look at them often." The other seventeen items are concerned with farm operations and will be of intense interest to the historian of agricultural methods. The postscript gives directions about drawing funds to keep things going.

5 These letters Cobbett never reprinted, but they are today easily available in Cobbett's Rural Rides, Edited by G. D. H. Cole (London, 1930), pp. 882-916. They are preceded by a description of North Wales, written on the same trip and first printed in the Register of September 20, I834. 
Letter 7 , from Cork, I give in full:

Cork, 16. Oct. 1834.

To Mr Dean.

Dear Sir,

Ah! a, a, a! I have got Emma's letter of the 8th. instant, and I have laughed an hour! I told you what was likely to happen! I was almost sure, that it would be so. ${ }^{7}$ I am very sorry for their sakes; but very glad for my own sake; for, as I often told Sammy, ${ }^{8}$ I knew, that (without any thing of this sort) we never could go on with her and her child. I have told little Emma to write to me, and to give me an account of the Lovers, if she can, and particularly whether he went down to the farm, and, if he did, what took place there.-We could not, and I always said so, go on with her, even if this had not happened; and, as to him, he was become of no use to me; and never could be of any use again.- So that, for my own sake, I am glad of the fight. And now, as to all points in poor little Emma's letter.

I. HORSE FEED. When tops and blades are gone, cut up the thick rows of Corn-plants in West-field; and cut them all up in the chaff-cutter, and mix barley-meal with them; and buy some barley for the purpose; or, buy oats, dry them well on the kiln; and have them ground for the purpose.-When all these corn-plants are gone, do the same with the corn-stalks, after you have gathered in the ears. ${ }^{9}$

2. CORN-EARs. You may now begin gathering. Put 50, or more, bushels of ears, with the husks on, on the kiln, and put the Thermometer (which Emma will send you) on the wall, near the corn. Never let the heat be more than 85 degrees. Turn the corn two or three times; and, when it is quite dry, take it off, and put it away, as I shall tell you presently.-Then, the stalks will be ready, in plenty, to cut up for the horses, as I before described.

3. CALVEs.-Let them die. They have been plague enough. I hope the 2 bull-calves will live. Spare no pains with them.

4. HoGs.-There will be some short, imperfect ears of corn; but, dry them all; for the green corn is not good for any thing to eat. When quite $d r y$, the pigs may have these.-

5. CABBAGEs. - By the time that you have got through the cabbagestumps, the mangle-wurzle [sic] tops will be ready. - Take the cart,

${ }^{6}$ Probably Dean's daughter.

${ }^{7}$ Mary (Mrs) Kenner left the farm and her husband \& child and went off to London to her lover, Gutsell! [This note written on the letter by Benjamin Tilly.]

8 Probably Dean's son.

${ }^{9}$ From the time of Cobbett's sojourn in the United States in $1817-1819$ he sought to introduce Indian corn to English agriculture. He grew it himself. In 1828 he published $A$ Treatise on Cobbett's Corn. In later editions of Cottage Economy, first published by him in 1822, he added a section on "Cobbett's Corn" (first in the I 83 I edition). 
and go up the rows; pull off all the leaves, top leaves and all.-And let the plants stand 'till about I oth November.

6. SPRING CABBAGEs.-Upon the ground, where the corn is now, in Dedman's field; and upon the ground, where the 4 rows of cabbages were, and upon the ground where the stumps are; upon all this ground, plant, on the 4 feet ridges, the earliest Spring-Cabbages. And, tell Fletcher to do this very nicely. If you could put some little dung under them, it would be good.

7. GEORGE. ${ }^{10}$ - No: I cannot keep George. There would be great impropriety in doing this. It is not my fault that his wife has gone away. I paid them a pound, and I promised them, that it should be a gift, if they both behaved well, 'till my return. I made a bargain to pay for their washing, and to give them twenty-one pounds a year; and I promised Mary 6 new gowns, if she behaved well, 'till I came back. But, she has dissolved the bargain: the husband is answerable for the wife; and, if he could not prevent her from leaving her service, that is no fault of mine. The law would allow me to refuse to pay them any thing. But I will pay them in full; and the account is as follows: they came, I think, on the 2oth of April. She was to have eleven pounds a year, and she went off on the 16 September; that is 21 weeks at $4^{\mathrm{s}} \cdot 2^{\frac{\mathrm{d} 3}{4}}$ a week.-George, 26 weeks, to 20 . October, at $4^{\mathrm{s}}$. a week.

\begin{tabular}{|c|c|}
\hline $\begin{array}{l}2 \text { I weeks at } 4^{\mathrm{s}} \cdot 2^{\mathrm{d} \frac{3}{4}} \text { a week } \ldots \ldots \ldots \ldots \\
26 \text { weeks at } 4^{8} . \ldots \ldots \ldots \ldots \ldots \ldots \ldots \ldots \ldots \ldots \ldots \ldots \ldots \ldots \ldots \ldots\end{array}$ & $\begin{array}{l}\mathfrak{f}_{4.8 .10} \frac{1}{2} \\
5 \cdot 4.0\end{array}$ \\
\hline Deduct the pound paid before... & $\begin{array}{l}9.12 .10 \frac{1}{2} \\
\text { I. O. } 0\end{array}$ \\
\hline alance due & f8. $12.10^{\frac{1}{2}}$ \\
\hline
\end{tabular}

Now, first pay Fletcher his demand for taking care of George's child, and pay the rest of the $\mathfrak{1} 8.12 .10 \frac{1}{2}$ to George; for the money is all his. The law gives him the wife's wages as well as his own. But, before you pay him, see that he take the child from Fletcher's, and, also, that he take it out of my house, if the mother have gone away and left it. Do not pay anything more, if she should be come back; and if she be come back, discharge them both: let neither stay an hour after you get this letter.-You need not take a receipt: pay in the presence of somebody.-I will write to Mr. Arkall, in a day or two, to get another maid. We will not have a married maid any more; for it is the devil all over to have men falling in love with married maids! - Sam will laugh at all this; for he knows, that I expected it.

8. CHEEse.-Tell $M^{\mathrm{rs}}$. Fletcher, that $\mathrm{I}$ am much obliged to her for her assistance in this case.-Do as well as you can till I can get another.-

${ }^{10}$ This was Mary's husband who was still at Normandy with his child though his wife was gone away. [Note written on the letter by Tilly.] 
9. THE MEN.-Read this to them, and tell them that $I$ am very much pleased at the account that you give me of their good behaviour, and they may be sure, that I will not fail to reward them for it.

IO. THE KEEPER'S BROTHER.-I should like you to have him, if he be an able young man, as a yearly servant in husbandry, rof a year, board and lodging.-But, he must must [sic] be able to plough; or to learn. In short, if he be a nice, sober young man, engage him.-I am glad you discharged John. ${ }^{11}$ He was too stiff.-

I I. THE WHEAT.-White wheat; drills a foot, or nearly, apart; thickish in the drill.- Trampled down with the drove of hogs and pigs, with a parcel of men and boys to keep them to their work! Be sure to do this!-The wheat may be damp for sowing; but, let it be real white wheat.-It need not be prime and dry.-The ground may be dryish, if you trample it well.-You will find enclosed a paper, which you must carry, yourself, to Godalming. You will want about 90 bushels of wheat, at $5^{\mathrm{s}}$. a bushel.-That will be $£ 22 . \mathrm{sio}$. - The rest will pay off George.-I am very much pleased that the land is in such prime order.- I hope the head-lands and side-lands will be made very neat. ${ }^{12}$

12. Remember me to Samuel, Tom Farr, and Marshall and Underwood and Edward Farr and all the men.-I wish you could all have seen me entering into this most beautiful city.

13. Clear the room that Mary slept in, and put corn into it, when it comes off the kiln.-Look at it well, to see that it does not mould. Make a fire in the room.- It can be husked in wet weather; and a little by candle-light.-

14. If you have got 2 barrels of i 8 gallons, you may NOW venture to brew some ale.-Before you could not.

15. I would enclose you, but I cannot, an account of my entry into this finest of all the cities I ever saw.- There were more than Eighty Thousand people! And the words "Welcome to Ireland" made the air ring.-I wish Sam had been with me, and I was within a nick of bringing him.-I have fine weather, good health, and a country where all think it an honour to see me.- How this would surprize the men, if they could see it.-Get them together (when you have in the Register) and read the paper to them, some evening, or of a Sunday.-Sam should have come; but I was afraid to leave her ${ }^{13}$ in the house alone.

11 John Farr, Tom Farr's brother. [Note written on the letter by Tilly.]

${ }^{12}$ This is a reference to item 14 in his directions in his letter of September 26 to Dean.

${ }^{13}$ Mary Kenner [Tilly's note]. It perhaps should be noted that in his letter to Dean on September 26, Cobbett spells her name "Kenning." In his item 18 of this letter he says: "I hope that all goes well in the house; and that Mrs. Kenning is very careful about the cheese. Mr. Martin is to go up with me, and to take one of his cheeses.-Tell her that I will be very good to her and her husband and child, if she take good care of this matter." 
When you go to Godalming, be sure to leave Sam in the house all the time.

I am your friend, $W^{m}$. Cobbett

It is clear that Cobbett engaged George before he had seen his wife. George was to work as one of the hands; his wife was to see to making cheese in the dairy, this cheese being one of the important products at Normandy Farm. It is clear also that Cobbett foresaw trouble-indeed, that trouble was in the air well before he left for Ireland. The little scandal is entertaining and revealing, for it shows from many points of view Cobbett's attitude towards his employees and associates. Others will find this letter interesting because of the detailed instructions given by Cobbett at long distance to an associate of long standing, for we must remember that at this writing Cobbett was seventy-two years of age. Still others will find great appeal in Cobbett's report of his reception in Cork.

In any event the Rutgers University Library is fortunate in possessing these documents from the hand of one of the greatest men England has known. 